\title{
Effect of fresh chlorella powder on improving qualities and storage condition of organic soybean tofu
}

\author{
Min-Jeong Kim, Chang-Ki Shim*, Yong-Ki Kim, Sung-Jun Hong, Jong-Ho Park, \\ Eun-Jung Han, Seok-Cheol Kim \\ Organic Agriculture Division, National Institute of Agricultural Science, RDA, Wanju 55365, Korea
}

\section{클로렐라 생균 분말이 유기농 두부의 품질과 저장성 향상에 미치는 영향}

\author{
김민정 · 심창기 $*$ 김용기 · 홍성준 · 박종호 · 한은정 · 김석철 \\ 농촌진흥청 국립농업과학원 유기농업과
}

\begin{abstract}
The purpose of this study was to investigate the effect of a fresh chlorella powder on yield, quality and self-life of organic soybean tofu. After added with a fresh chlorella powder, yields, physical properties, color, shelf-life and sensory properties of the organic soybean tofu added with chlorella powder was compared to the properties of soybean tofu. The yield of soybean tofu increased with the addition of more than $1 \%$ chlorella powder. Hardness of the organic soybean tofu with chlorella significantly increased compared to that of the soybean tofu. However, Hunter's color values of $\mathrm{L}$, a, and $b$ decreased by increases in the chlorella powder concentration. Total microbial population of the soybean tofu was higher than that of the organic soybean tofu with chlorella. However, pH of chlorella tofu decreased during storage period at $4{ }^{\circ} \mathrm{C}$. After 7 days storage at $4{ }^{\circ} \mathrm{C}$, the total microbial population decreased significantly with the addition of $2 \%$ chlorella powder. The $L$ and a value of chlorella tofu was increased. On the other hand, the $b$ value of chlorella tofu was decreased during storage. The results revealed that a fresh chlorella powder was a useful material to improve yield, quality and storage condition of the organic soybean tofu.
\end{abstract}

Key words : fresh chlorella powder, organic soybean tofu, quality, storage

\section{서 론}

콩은 식물성 단백질이 $40 \%$ 이상을 차지하고 있어 훌륭한 단백질원으로 알려져 있다. 이 이외에도 아미노산, 지방이 풍부하고 수용성 색소인 daidzin, genistin 등과 같은 isoflavones 성분이 많아 콜레스테롤 저항, 항산화작용, 항암 작용을 하는 것으로 잘 알려져 있다. 콩은 영양분이 풍부한 반면 바로 섭취하게 되면 양분효율이 떨어지는 반면, 두부 는 소화흡수율이 $96 \%$ 로 매우 높은 양질의 단백질 공급

*Corresponding author. E-mail : ckshim@korea.kr Phone : 82-63-238-2557, Fax : 82-63-238-3824

Received 7 November 2016; Revised 14 November 2016; Accepted 24 November 2016.

Copyright (c) The Korean Society of Food Preservation. All rights reserved.
식품으로 알려지게 되었다 $(1,2)$. 두부는 우리나라 전통식품 중의 하나로 lysine과 같은 필수 아미노산이 풍부하고 소화 율이 높아 양질의 단백질 공급원으로 널리 이용되는 식품 중의 하나이다 $(3,4)$. 그러나 두부는 $80 \%$ 이상의 수분 때문 에 보존성이 열악하여 저장과 유통면에서 어려움이 많은 식품이다(5).

시중의 포장 두부는 포장 후 $65 \sim 80^{\circ} \mathrm{C}$ 에서 열처리하고 냉각시킨 후 냉장 유통되고 있다. 두부의 저장성 향상을 위하여 물리적으로 두부를 microwave나 고압으로 처리하 는 방법(6), $\mathrm{Ca}^{2+}$ 이온 이외에 식물체 유래 항균물질 첨가(7), 두부침지액의 보존성을 향상시킬 수 있도록 침지액의 $\mathrm{pH}$ 를 조절하거나(8), 유기산(9)이나 키토산(10) 등을 첨가하는 방법 등이 보고되어 있으며, 그러나 포장하지 않은 두부는 저장기간이 실온에서 1 2일로 극히 짧아 유통상의 큰 어려 움을 초래 하고 있다(5). 
클로렐라는 광합성을 하는 단세포 녹조류로 세포내에 엽록소, 단백질, 비타민, 미네랄 등 다양한 기능성 성분을 함유하고 있는 것으로 보고되었으며 $(11,12)$, 클로렐라로부 터 지방과 단백질을 생산하기 위한 연구가 활발하게 진행되 었다(13). 최근 들어 클로렐라를 첨가한 라면, 국수, 김치, 떡 등 일반식품으로 클로렐라의 용도가 확대되고 있으며 (14-16) 특히 유기농작물인 콩나물, 딸기, 엽채류 재배기간 중 클로렐라 배양액을 처리시 과육의 당도뿐만 아니라 저장 성도 증가하는 것으로 보고하였다 $(17,18)$.

따라서 본 연구는 두부의 이용성을 향상시키고자 두부 제조과정 중에 클로렐라 생균 분말을 첨가하여 클로렐라 두부의 수율, 물리성, 저장성 등에 미치는 영향을 비교분석 하였다.

\section{재료 및 방법}

\section{실험재료}

두부 제조시 공시한 콩은 충남 서산 유기농 콩재배 농가 에서 2014년에 재배하여 수확한 유기농 대원콩을 사용 하 였으며, 클로렐라(Chlorella vulgaris CHK0008)는 농촌진흥 청 유기농업과실에서 수집하여 분리, 동정한 후, 광배양하 여 농축 후 동결 건조한 것을 사용하였다. 응고 제로는 $\mathrm{CaCl}_{2} \cdot 2 \mathrm{H}_{2} \mathrm{O}$ 를 두유액에 대하여 $0.3 \%$ 로 첨가하였다.

\section{일반분석}

동결건조한 클로렐라 분말의 수분, 조단백질, 조지방, 회 분함량을 Association of official chemist(AOAC)법(19)에 준 하여 수분은 $105^{\circ} \mathrm{C}$ 건조법, 회분은 건식회화법, 조단백질은 Micro-kjeldahl법으로 분석하였으며, 조지방은 Soxhlet 추출 법으로 분석하였다.

\section{두부의 제조 및 저장}

기존의 연구자들이 사용한 방법 $(10,20)$ 을 변형하여 클로 렐라두부를 제조하였다. 이물질을 제거하고 깨끗이 수세한 대두 $100 \mathrm{~g}$ 을 실온에서 15 시간 수침하여 세척하고 $1 \mathrm{~L}$ 의 증류수를 가한 후 가정용 분쇄기(Hanil, HMF-3000S, Seoul, Korea)로 5 분간 고속으로 2회 마쇄하였다. 마쇄한 두유액을 $95^{\circ} \mathrm{C}$ 에서 15 분간 끓인 후 Cheesecloth로 두유액만을 남겼 다. 이 두유액에 즉시 클로렐라 생균 분말을 대두무게를 기준으로 $0.5 \sim 2 \%(\mathrm{w} / \mathrm{w})$ 첨가하고 잘 혼합한 후, $80^{\circ} \mathrm{C}$ 에서 응고제 $\left(0.3 \% \mathrm{CaCl}_{2} \cdot 2 \mathrm{H}_{2} \mathrm{O}\right)$ 를 첨가하고 25 분간 방치한 후, 응고물을 성형틀 $(10 \times 10 \times 4 \mathrm{~cm})$ 에 옮기고 30 분간 압착 성형 하여 두부를 제조하였다. 만들어진 두부는 용기에 침지액 $150 \mathrm{~mL}$ 를 넣고 $4^{\circ} \mathrm{C}$ 에서 7 일간 저장하면서 실험을 진행하 였다.
수율, 색도 및 Texture 측정

두부의 수율은 압착 성형 후 수침시킨 두부를 꺼내어 10 분 정도 바구니에 정치하여 두부표면의 수분을 제거시킨 후 무게를 측정하여 계산하였다.

수율 $(\%)=$ 두부생산량 $(\mathrm{g}) \times \frac{\text { 두부의 고형량 }(\%)}{18 \%} \times \frac{100}{\text { 원료사용량 }(\mathrm{g})}$

성형된 두부의 색도는 두부를 일정한 크기 $(6.0 \times 4.0 \times 1.5$ $\mathrm{cm}$ )로 절단한 다음, 분광색차계(Color/ difference meter CM-3500d, Konica Minolta, Tokyo, Japan)를 이용하여 명도 (L, lightness), 적색도(a, redness), 황색도(b, yellowness)을 10 회 측정하여 평균값으로 얻었으며, 이때 표준 백색판 (White plate, Konica Minolta, Tokyo, Japan)의 L, a, b값은 각각 $98.47,0.20,-0.65$ 이었다.

두부의 Texture(TA-1, Ametek M \& CT, Largo, FL, USA) 는 Jung 등(21)의 방법을 변형하여 두부를 일정한 크기 $(6.0 \times 4.0 \times 1.5 \mathrm{~cm})$ 로 절단, Rheometer(Compac-100, SUN Scientific Co., Ltd., Tokyo, Japan)를 사용하여 견고성 (hardness), 깨짐성(fracturability), 탄성(elasticity), 부착성 (adhesiveness), 응집성(cohesiveness), 검성(gumminess), 씹 힘성(chewiness)을 3회 측정하여 평균값으로 나타내었다. 측정조건은 test type은 mastication로 하였으며 table speed 는 $60 \mathrm{~mm} / \mathrm{min}$ 이었고 adaptor type은 $30 \mathrm{~mm}$ circle (No. 11)로 하였다.

\section{두부의 미생물 수 및 $\mathrm{pH}$ 측정}

제조한 두부의 저장 시간의 경과에 따른 미생물수의 변 화는 두부 $1 \mathrm{~g}$ 을 멸균 증류수 $9 \mathrm{~mL}$ 에 혼합하여 분쇄한 후 10 배씩 희석한 후, 희석액 $100 \mu \mathrm{L}$ 를 Tryptic soy agar plate(TSA, Pancreatic digest of casein $17.0 \mathrm{~g}$, Papaic digest of soybean $3.0 \mathrm{~g}$, Dextrose $2.5 \mathrm{~g}$, Sodium chloride $5.0 \mathrm{~g}$, Dipotassium phosphate $2.5 \mathrm{~g}$, Agar $20 \mathrm{~g}$, 멸균증류수 1,000 $\mathrm{mL}$ )에 분주한 후, 멸균된 삼각유리봉으로 평판도말 하였 다. 도말 후 $28^{\circ} \mathrm{C}$ 에서 48 시간 배양하여 형성된 colony를 계측하고 미생물의 균수는 시료 g당 colony forming units(CFU/g)로 나타내었다.

Table 1. The conditions for measurement of soybean tofu texture with Rheometer

\begin{tabular}{cc} 
Max. force of load cell & $2 \mathrm{~kg}$ \\
Cross head speed & $100 \mathrm{~mm} / \mathrm{min}$ \\
Chart speed & $100 \mathrm{~mm} / \mathrm{min}$ \\
Clearance & $18 \mathrm{~mm}$ \\
Sample size & $60 \times 60 \times 24 \mathrm{~mm}$ \\
Compression ratio & 0.75 \\
\hline
\end{tabular}


저장 중 두부의 $\mathrm{pH}$ 는 두부 $1 \mathrm{~g}$ 을 멸균 증류수 $9 \mathrm{~mL}$ 에 혼합하여 분쇄한 후 $\mathrm{pH}-\operatorname{meter}(780 \mathrm{pH}$ meter, MetrohmToledo, Herisau, Switzerland)를 이용하여 직접 측정하였다.

\section{통계처리}

클로렐라 두부 실험결과는 3반복으로 하였고, 반복마다 10 포트씩 정식하였다. 수집된 자료의 정리와 통계는 SAS프 로그램(SAS 9.2, SAS Institute, Cary, NC, USA)를 이용하여, 분산분석을 실시하였다. 처리 평균간 비교는 Duncan multiple range test로 유의확률 $\mathrm{p}<0.05$ 인 경우 통계적으로 유의 하다고 인정하였다.

\section{결과 및 고찰}

\section{클로렐라의 이화학적 특성}

본 연구의 클로렐라 두부제조에 사용된 클로렐라 생균의 세포내 수분, 회분, 조단백질, 조지방 함량을 분석하였더니, 수분함량은 약 $1.54 \%$ 이었고 회분함량은 $6.53 \%$ 이었다. 특 히, 클로렐라 생균분말의 조단백질과 조지방 함량은 각각 $54.56 \%$ 와 $2.45 \%$ 이었다(Table 2).

Park과 Cho(15)에 의하면 (주)대상에서 제조한 시판 클로 렐라 추출물분말의 유용성분 함량중 수분과 회분함량은 각각 $2.28 \%$ 와 $7.16 \%$ 이며 조단백질과 조지방 함량은 각각 $66.91 \%$ 와 $0.92 \%$ 인 것으로 보고한 바 있다(한국보건산업진 흥원, 2001). Atsushi(11)에 의하면 클로렐라는 고 영양 식품 인 우유나 달걀에 비해 단백질, 비타민, 무기질 함량이 매우 높아, 클로렐라의 성분 중에 단백질이 $60.6 \%$, 지방산은 $12.8 \%$, 회분은 $4.5 \%$ 인 것으로 보고하였다.

Table 2. Composition of chlor ella powder

\begin{tabular}{cc}
\hline Characteristics & Chlorella powder $(\%)$ \\
\hline Moisture & $1.54 \pm 0.01^{1)}$ \\
Crude protein & $54.56 \pm 0.16$ \\
Crude lipid & $2.45 \pm 0.02$ \\
Crude ash & $6.53 \pm 0.11$ \\
\hline
\end{tabular}

${ }^{1)}$ The values are mean $\pm \mathrm{SD}(\mathrm{n}=4)$.

\section{클로렐라 두부의 수율}

클로렐라 두부 제조 시 첨가한 클로렐라 분말의 농도에 따른 두부의 수율을 조사하였더니, 클로렐라 분말의 농도 가 증가 할수록 두부의 수율은 유의적으로 증가하여 일반두 부에 비해 10.0 37.7\% 더 높은 것으로 나타났다(Table 3). 두부에 첨가한 4 개의 클로렐라 분말 농도 중, $2.0 \%$ 클로렐 라 분말을 첨가하였을 때 두부의 수율이 $243.3 \%$ 로 가장 높게 나타났다.
Table 3. Effect of the concentration of chlorella powder on the yield of soybean tofu

\begin{tabular}{lccccc}
\hline & \multicolumn{5}{c}{ Concentration of chlorella (\%) } \\
\cline { 2 - 6 } & 0.0 & 0.5 & 1.0 & 1.5 & 2.0 \\
\hline Yield (\%) & $205.6 \pm 2.7^{\mathrm{el})}$ & $215.6 \pm 3.4^{\mathrm{d}}$ & $226.2 \pm 2.1^{\mathrm{c}}$ & $232.9 \pm 4.1^{\mathrm{b}}$ & $243.3 \pm 3.2^{\mathrm{a}}$ \\
\hline${ }^{11}$ Means followed by the same letters are not significantly different at $\mathrm{p} \leq 0.05$ by \\
Duncan multiple range test.
\end{tabular}

Chang 등(22)에 의하면 기능성 두부제조를 위해 미국산 수입대두에 클로렐라 제품분말을 $1.0 \%$ 첨가했을 때, 클로 렐라분말을 첨가한 두부의 수율이 일반두부에 비하여 $10 \%$ 이상 향상된 것으로 보고하였다. 두부의 수율 및 품질은 콩의 이화학적 성분조성과 밀접한 관계가 있으며, 이들의 조성은 대두 품종에 따라 현저한 차이가 있는 것으로 보고 되어 있다 $(23,24)$. 특히 두부 및 장류용 콩의 단백질 함량이 높은 콩으로 제조한 것이 단백질과 지방 성분의 비율이 높다고 알려져 있으며, 콩의 성분조성은 가공식품의 성분 조성과 수율에 영향을 준다고 보고 된 바 있다(25,26).

본 연구결과에서는 동일한 농도의 클로렐라 분말을 첨가 했을 때, Kim 등(20)이 보고한 결과보다 생균클로렐라두부 의 수율이 더 높은 것으로 조사되었다. 이러한 결과는 실험 에 사용된 콩의 품종과 클로렐라 생균 분말을 사용한 것이 큰 원인으로 작용했을 것으로 판단된다.

\section{클로렐라 두부의 물리성}

두부 제조시 클로렐라 생균 분말을 농도별로 첨가하였을 때 두부의 물리성(견고성, 깨짐성, 탄성, 부착성, 응집성, 검성, 씹힘성)에 미치는 영향을 조사하였더니, 클로렐라를 첨가하지 않은 두부의 물리성에 비해 클로렐라 생균 분말을 첨가한 두부의 물리성이 2.2 90.9\%까지 증가하는 것으로 조사되었다(Table 4). 특히 $2.0 \%$ 클로렐라 생균 분말을 첨가 하였을 때 두부의 견고성 $(0.88 \mathrm{~kg})$, 응집성 $(0.37 \mathrm{~kg})$, 부착성 $(0.97)$, 탄성 $\left(0.94 \mathrm{~cm}^{2}\right)$, 검성 $(0.49)$, 씹힘성 $(0.42)$ 이 가장 높 게 증가하는 것으로 나타났다(Table 4).

$\operatorname{Kim}$ 등(20)에 의하면 기능성 두부제조를 위해 첨가한 클로렐라로 인해 두부의 물성 중 견고성, 검성, 씹힘성이 증가하였으나 응집성과 탄성은 클로렐라의 첨가와 무관하 며 관능적 특성은 조직감 이외의 항목에서는 일반두부와 통계적으로 유의적인 차이가 없는 것으로 보고하였다. 또 한 Baek 등(26)에 의하면 갈조류인 미역을 두부 제조시 첨 가했을 때, 일반두부에 비해 견고성이 감소하고 탄력성과 응집성은 증가하는 것으로 보고를 하여 연구결과마다 다소 의 차이점이 있는 것 같다. 본 연구결과에서는 클로렐라 생균 분말을 첨가했을 때 일반두부에 비해 7 가지의 물리성 이 모두 증가하는 것으로 보아 클로렐라 생균 분말 첨가가 두부의 물리성 변화에 영향을 주는 것으로 생각한다. 이러 한 특성은 두부의 유통과정과 샐러드용 두부의 개발 등 
Table 4. Comparison of textural properties of soybean tofu prepared with a fresh chlorella powder

\begin{tabular}{cccccccc}
\hline \multirow{2}{*}{$\begin{array}{c}\text { Concentrations of } \\
\text { chlorella }(\%)\end{array}$} & \begin{tabular}{c} 
Hardness \\
\cline { 2 - 7 }
\end{tabular} & $\begin{array}{c}\text { Fracturability } \\
(\mathrm{kg})\end{array}$ & Elasticity & $\begin{array}{c}\text { Adhesiveness } \\
\left(\mathrm{cm}^{2}\right)\end{array}$ & Cohesiveness & Gumminess & Chewiness $^{2)}$ \\
\hline 0.0 & $0.58 \pm 0.04^{\mathrm{d} 3)}$ & $0.23 \pm 0.01^{\mathrm{c}}$ & $0.92 \pm 0.01^{\mathrm{c}}$ & $0.60 \pm 0.02^{\mathrm{e}}$ & $0.41 \pm 0.01^{\mathrm{c}}$ & $0.24 \pm 0.02^{\mathrm{d}}$ & $0.22 \pm 0.02^{\mathrm{c}}$ \\
0.5 & $0.61 \pm 0.04^{\mathrm{d}}$ & $0.25 \pm 0.01^{\mathrm{c}}$ & $0.94 \pm 0.01^{\mathrm{b}}$ & $0.69 \pm 0.05^{\mathrm{d}}$ & $0.43 \pm 0.01^{\mathrm{c}}$ & $0.27 \pm 0.02^{\mathrm{c}}$ & $0.25 \pm 0.02^{\mathrm{c}}$ \\
1.0 & $0.70 \pm 0.04^{\mathrm{c}}$ & $0.29 \pm 0.02^{\mathrm{b}}$ & $0.95 \pm 0.01^{\mathrm{b}}$ & $0.83 \pm 0.02^{\mathrm{c}}$ & $0.45 \pm 0.01^{\mathrm{b}}$ & $0.31 \pm 0.03^{\mathrm{c}}$ & $0.30 \pm 0.03^{\mathrm{b}}$ \\
1.5 & $0.74 \pm 0.06^{\mathrm{b}}$ & $0.30 \pm 0.04^{\mathrm{b}}$ & $0.95 \pm 0.01^{\mathrm{b}}$ & $0.86 \pm 0.01^{\mathrm{b}}$ & $0.46 \pm 0.01^{\mathrm{b}}$ & $0.34 \pm 0.03^{\mathrm{b}}$ & $0.30 \pm 0.03^{\mathrm{b}}$ \\
2.0 & $0.88 \pm 0.10^{\mathrm{a}}$ & $0.37 \pm 0.05^{\mathrm{a}}$ & $0.97 \pm 0.01^{\mathrm{a}}$ & $0.94 \pm 0.08^{\mathrm{a}}$ & $0.49 \pm 0.01^{\mathrm{a}}$ & $0.43 \pm 0.05^{\mathrm{a}}$ & $0.42 \pm 0.05^{\mathrm{a}}$ \\
\hline
\end{tabular}

${ }^{1)}$ Gumminess, Hardness $\times$ Cohesiveness.

${ }^{2)}$ Chewiness, Hardness $\times$ Cohesiveness $\times$ Elasticity.

${ }^{3)}$ Means followed by the same letters are not significantly different at $\mathrm{p} \leq 0.05$ by Duncan multiple range test.

다양한 용도의 개발에 장점으로 작용할 수 있을 것으로 판단된다.

\section{클로렐라 두부의 색도}

두부 제조시 클로렐라 생균 분말 첨가가 두부의 색도변 화에 어떠한 영향을 미치는지 조사하였더니, 클로렐라 생 균 분말의 농도가 증가할수록 일반두부와 비교하였을 때 색도값 중 $\mathrm{L}$ 과 $\mathrm{a}$ 는 모두 낮아지는 반면, $\mathrm{b}$ 는 증가하는 것으 로 조사되었다(Table 5, Fig. 1).

두부 응고제인 $\mathrm{CaSO}_{4}$ 대신에 오미자즙과 매실즙을 사용 하여 제조한 두부의 색도를 비교한 바, 매실즙 두부는 일반 두부와 색도값 $\mathrm{L}, \mathrm{a}, \mathrm{b}$ 에서 차이가 없었지만 오미자즙 두부 는 밝기와 황색도가 각각 일반두부보다 2.0고 3.7 낮아진 것으로 보고하였다(21). Baek 등(26)은 클로렐라와 유사한 갈조류인 미역을 두부에 첨가하였을 경우 밝기와 적색도는 감소하고 황색도는 약간 증가하는 것으로 보고하였으며 Kim 등(27)은 인삼분말 또는 추출액 첨가로 밝기는 낮아지 고 적색도와 황색도는 증가하는 것으로 보고하여 두부의 특성을 개선하기 위하여 첨가한 물질에 따라 실험결과의 차이가 있었다.

그러나 Kim 등(20)은 제품용 클로렐라분말이 두부의 색 도에 미치는 영향을 조사하였더니 일반 두부에 비해 밝기, 적색도, 황색도가 모두 감소하는 것으로 보고하여 본 실험 결과와 유사한 것으로 생각된다.

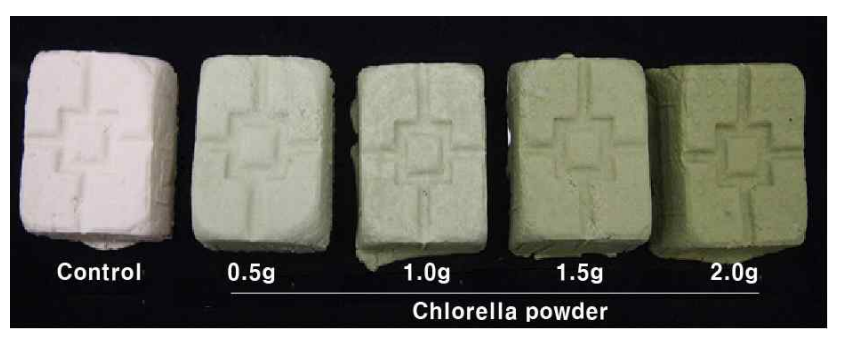

Fig. 1. Comparison of color texture of Daewon soybean tofu prepared with four concentrations of a fresh chlorella powder.
Table 5. Comparison of color value of soybean tofu prepared with a fresh chlorella powder

\begin{tabular}{ccccc}
\hline $\begin{array}{c}\text { Concentration of } \\
\text { chlorella (\%) }\end{array}$ & L (Lightness) & a (Redness) & $\mathrm{b}$ (Yellowness) & $\Delta \mathrm{E}$ \\
\hline 0.0 & $88.71 \pm 0.70^{\mathrm{a} 1)}$ & $-1.97 \pm 0.08^{\mathrm{a}}$ & $12.91 \pm 0.77^{\mathrm{e}}$ & $19.3 \pm 0.7^{\mathrm{c}}$ \\
0.5 & $87.15 \pm 0.16^{\mathrm{b}}$ & $-4.03 \pm 0.06^{\mathrm{b}}$ & $14.64 \pm 0.39^{\mathrm{d}}$ & $33.5 \pm 0.6^{\mathrm{a}}$ \\
1.0 & $85.11 \pm 0.42^{\mathrm{c}}$ & $-4.75 \pm 0.13^{\mathrm{c}}$ & $15.58 \pm 0.38^{\mathrm{c}}$ & $25.2 \pm 0.7^{\mathrm{b}}$ \\
1.5 & $81.78 \pm 1.39^{\mathrm{d}}$ & $-5.58 \pm 0.07^{\mathrm{d}}$ & $15.95 \pm 0.10^{\mathrm{b}}$ & $22.4 \pm 0.4^{\mathrm{c}}$ \\
2.0 & $71.70 \pm 1.18^{\mathrm{e}}$ & $-6.49 \pm 0.18^{\mathrm{e}}$ & $18.51 \pm 0.55^{\mathrm{a}}$ & $22.3 \pm 0.3^{\mathrm{c}}$ \\
\hline
\end{tabular}

${ }^{1)}$ Means followed by the same letters are not significantly different at $\mathrm{p} \leq 0.05$ by Duncan multiple range test.

\section{클로렐라 두부의 저장성}

두부 제조시 클로렐라 생균 분말 첨가하여 두부의 저장 성에 미치는 영향을 $\mathrm{pH}$ 와 미생물밀도의 변화로 조사하였 더니, 제조한 두부를 $4^{\circ} \mathrm{C}$ 로 보관하면서 $\mathrm{pH}$ 와 총균수의 변화 를 측정한 결과 일반두부에 비해 클로렐라 두부의 $\mathrm{pH}$ 가 적게 감소되었으며, 총균수는 현저히 낮은 것으로 나타났 다(Fig. 2). 두부의 저장 7일 후, 일반두부의 $\mathrm{pH}$ 는 6.4 에서 5.6으로 0.8 정도 감소하였으나 클로렐라 두부( $\mathrm{pH}$ 5.9 6.3) 의 경우는 0.4 정도 감소되어 클로렐라 생균 분말의 농도가 높을수록 두부의 $\mathrm{pH}$ 변화가 적은 것으로 나타났다. 또한 두부 저장 중의 총균수도 클로렐라 생균 분말의 농도가 높을수록 총균수의 밀도가 유의하게 적게 조사되었다. 특 히 $1.0 \%$ 이상의 클로렐라 생균 분말을 처리한 두부의 경우 일반두부에 비해 4 배 이상 총균수가 낮아지는 것으로 조사 되었다.

$\operatorname{Kim}$ 등(17) 제조한 두부를 $15^{\circ} \mathrm{C}$ 로 보관하면서 $\mathrm{pH}$ 와 총균 수의 변화를 측정한 결과 클로렐라를 $0.5 ~ 1.0 \%$ 첨가한 두부 에서 $\mathrm{pH}$ 의 감소와 미생물 생육이 억제된다는 본 실험과 유사한 결과를 보고하였다. 또한 클로렐라를 첨가한 물김 치를 $4^{\circ} \mathrm{C}$ 로 저장하면 $\mathrm{pH}$ 의 변화는 거의 없으나 젖산균의 밀도가 감소하는 것으로 보고한 결과(14)도 있어 두부제조 공정에 클로렐라를 첨가하면 두부의 저장성을 유지하는데 도움이 될 수 있을 것으로 판단된다. 

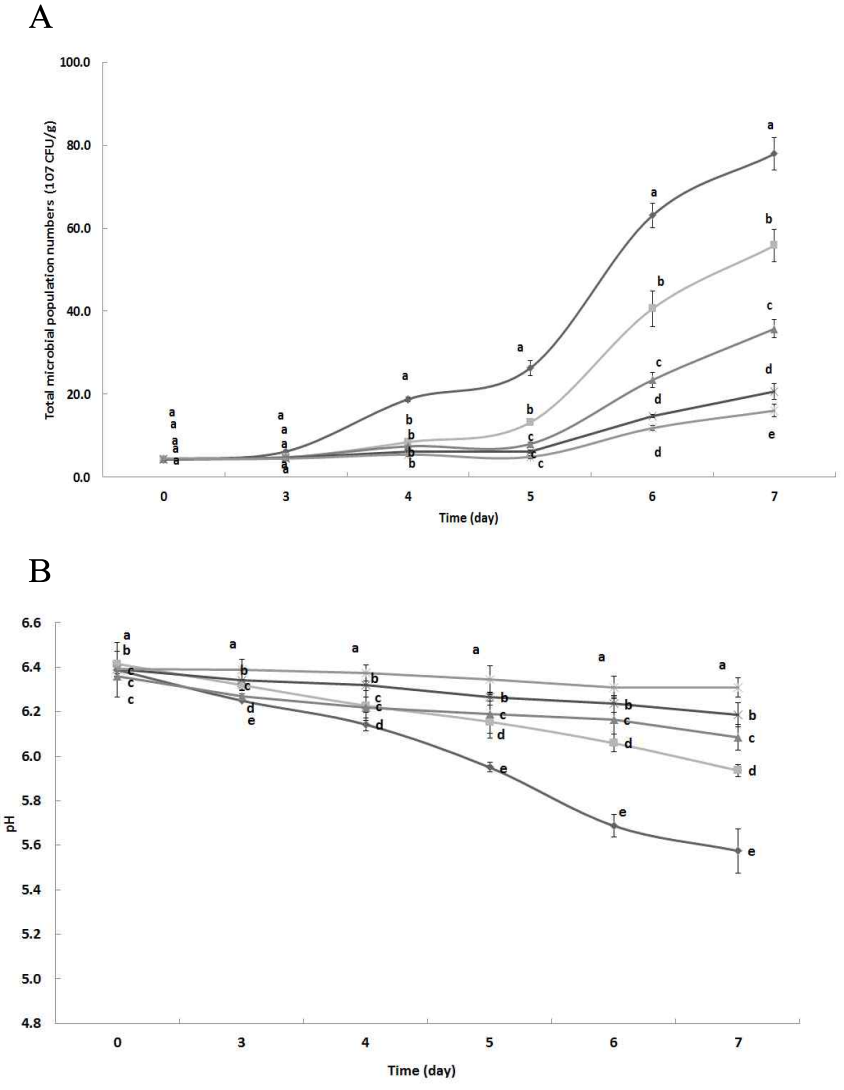

Fig. 2. Changes of $\mathrm{pH}(\mathrm{A})$ and total microbial population numbers (B) in organic soybean tofu during storage at $4^{\circ} \mathrm{C}$.

$\rightarrow$ Control $\rightarrow-0.5 \%$ Chlorella $\rightarrow-1 \%$ Chlorella $\rightarrow 1.5 \%$ Chlorella $\rightarrow 2.0 \%$ Chlorella

Each experimental data point represents the average value and the error bar shows the standard error from the mean. Means followed by the same letters are not significantly different at $\mathrm{p} \leq 0.05$ by Duncan multiple range test.

\section{저장 후 클로렐라 두부의 색상 변화}

클로렐라 생균 분말을 농도별로 첨가하여 만든 두부의 저장성 시간의 경과에 따른 색도변화의 결과는 Table 6과 같다. 저장기간이 증가함에 따라 두부의 $\mathrm{L}$ 값과 $\mathrm{a}$ 값이 증가 하였으나 $\mathrm{b}$ 값은 낮아지는 경향을 보였으며 통계적으로 유 의한 차이를 나타냈다. 특히 무처리 두부의 색상변화가 클 로렐라 처리두부에 비해 유의하게 크게 변하는 것으로 조사 되었다. 4 가지 농도의 클로렐라 두부 중에서는 $2.0 \%$ 클로렐 라 두부의 색상변화가 저장시간의 경과에 따라 가장 적게 두부표면의 색깔이 변하는 것으로 나타났다(Table 6).

$\mathrm{Jeon}$ 과 $\mathrm{Kim}(28)$ 은 설록차, 로즈마리, 라벤더 등의 허브를 첨가한 두부의 저장 중 색도변화를 연구한 결과 $\mathrm{L}$ 값은 증가 하였으나 $\mathrm{b}$ 값은 감소하는 경향을 보이는 것으로 보고하였 다. Park 등(2)은 강황추출물을 첨가한 두부의 저장 중색상 의 변화를 측정하였더니 $\mathrm{L}$ 값과 $\mathrm{a}$ 값은 저장시간이 경과함에 따라 낮게 나타났으나 $\mathrm{b}$ 값은 증가하는 것으로 보고하였다. 이러한 결과들은 두부에 포함된 허브나 강황의 색 성분이 침지액으로 빠져나왔기 때문이라 해석하고 있다.
Table 6. Comparison of color value of soybean tofu prepared with a fresh chlor ella powder (CP) during storage at $4{ }^{\circ} \mathrm{C}$

\begin{tabular}{cccccc}
\hline & \multirow{2}{*}{ Treatment } & \multicolumn{4}{c}{ Storage time (days) } \\
\cline { 3 - 6 } & & 0 & 3 & 5 & 7 \\
\hline \multirow{2}{*}{ L } & $0.5 \%$ Chlorella & $85.1^{\mathrm{cl} 1}$ & $85.9^{\mathrm{c}}$ & $86.0^{\mathrm{c}}$ & $87.5^{\mathrm{c}}$ \\
(Lightness) & $1.0 \%$ Chlorella & $87.1^{\mathrm{c}}$ & $87.5^{\mathrm{c}}$ & $88.2^{\mathrm{c}}$ & $89.1^{\mathrm{c}}$ \\
& $1.5 \%$ Chlorella & $81.8^{\mathrm{b}}$ & $82.0^{\mathrm{b}}$ & $82.2^{\mathrm{b}}$ & $83.3^{\mathrm{b}}$ \\
& $2.0 \%$ Chlorella & $71.7^{\mathrm{a}}$ & $71.8^{\mathrm{a}}$ & $72.0^{\mathrm{a}}$ & $73.0^{\mathrm{a}}$ \\
& Control & $88.7^{\mathrm{d}}$ & $90.7^{\mathrm{d}}$ & $94.0^{\mathrm{d}}$ & $94.9^{\mathrm{d}}$ \\
\hline \multirow{4}{*}{ (Redness) } & $0.5 \%$ Chlorella & $-4.0^{\mathrm{d}}$ & $-4.7^{\mathrm{c}}$ & $-5.7^{\mathrm{b}}$ & $-6.1^{\mathrm{b}}$ \\
& $1.0 \%$ Chlorella & $-4.8^{\mathrm{c}}$ & $-5.5^{\mathrm{b}}$ & $-6.5^{\mathrm{a}}$ & $-6.9^{\mathrm{a}}$ \\
& $1.5 \%$ Chlorella & $-5.6^{\mathrm{b}}$ & $-5.7^{\mathrm{b}}$ & $-6.4^{\mathrm{a}}$ & $-6.7^{\mathrm{a}}$ \\
& $2.0 \%$ Chlorella & $-6.5^{\mathrm{a}}$ & $-6.6^{\mathrm{a}}$ & $-6.6^{\mathrm{a}}$ & $-6.2^{\mathrm{b}}$ \\
& Control & $-2.0^{\mathrm{e}}$ & $-3.7^{\mathrm{d}}$ & $-4.0^{\mathrm{b}}$ & $-6.0^{\mathrm{b}}$ \\
\hline \multirow{3}{*}{$\mathrm{b}$} & $0.5 \%$ Chlorella & $14.6^{\mathrm{b}}$ & $15.1^{\mathrm{c}}$ & $15.8^{\mathrm{c}}$ & $16.6^{\mathrm{c}}$ \\
& $1.0 \%$ Chlorella & $15.6^{\mathrm{b}}$ & $16.8^{\mathrm{b}}$ & $17.4^{\mathrm{b}}$ & $18.0^{\mathrm{b}}$ \\
(Yellowness) & $1.5 \%$ Chlorella & $16.0^{\mathrm{b}}$ & $16.6^{\mathrm{b}}$ & $17.1^{\mathrm{b}}$ & $17.5^{\mathrm{b}}$ \\
& $2.0 \%$ Chlorella & $18.5^{\mathrm{a}}$ & $19.0^{\mathrm{a}}$ & $19.4^{\mathrm{a}}$ & $19.7^{\mathrm{a}}$ \\
& Control & $12.9^{\mathrm{c}}$ & $13.6^{\mathrm{d}}$ & $16.1^{\mathrm{c}}$ & $17.5^{\mathrm{c}}$ \\
\hline
\end{tabular}

${ }^{1)}$ Means followed by the same letters are not significantly different at $p \leq 0.05$ according to Fisher's protected least significant difference by Duncan multiple range test.

클로렐라는 다량의 엽록소를 함유하고 있으나 생균의 경우 세포가 건조되었지만 살아 있는 상태로 존재하기 때문 에 세포벽으로부터 색소가 빠져 나올 수 없을 것으로 판단 된다. 다만 이러한 클로렐라 첨가에 따른 두부 저장중의 색상변화 결과는 앞에서 두부 저장 중의 $\mathrm{pH}$ 나 미생물의 밀도변화에 있어서도 무처리에 비해 클로렐라를 첨가한 두부의 $\mathrm{pH}$ 변화가 적고 미생물의 총균수가 낮아져 저장성 을 증진하는 것으로 판단된다.

\section{요 약}

두부는 단백질 식품으로서 기호성이 높고 소화율이 높지 만 보존성이 극히 불량한 것이 단점이다. 본 연구의 목적은 클로렐라 생균 분말을 유기농 두부에 첨가할 경우 두부의 수율, 품질, 저장성에 미치는 영향을 조사하였다. 건조 대두 를 기준으로 클로렐라 분말을 $0.5 \sim 2 \%$ 첨가하여 제조한 두 부의 수율, 물성, 색도, 저장성 및 관능적인 특성을 일반 두부와 비교 하였다. 클로렐라 두부의 수율은 일반 두부에 비하여 $10 \%$ 이상 향상 되었다. 클로렐라를 첨가함으로써 두부의 물리성 중 견고성, 검성과 씹힘성이 증가 하였으며, 색도는 $\mathrm{L}$ 값, $\mathrm{a}$ 값, $\mathrm{b}$ 값 모두 첨가량에 비례하여 감소하였다. 두부를 $4{ }^{\circ} \mathrm{C}$ 저장하면, 일반 두부의 총균수는 클로렐라 두부 보다 높은 반면 $\mathrm{pH}$ 는 감소하였다. 저장 7 일 후, $2 \%$ 클로렐 
라 두부의 총균수가 일반 두부에 비해 현저히 억제되었다. 클로렐라 두부 저장기간의 증가에 따라 두부의 $\mathrm{L}$ 값과 $\mathrm{a}$ 값 이 증가하였으나 $\mathrm{b}$ 값은 낮았다. 따라서 클로렐라 생균 분말 을 첨가하면 투부의 저장성 향상에 기여할 뿐만 아니라 유기농 두부의 수율, 품질과 저장성을 증진하는데 효과적 인 첨가물임을 확인되었다.

\section{감사의 글}

본 연구는 농촌진흥청 공동연구사업(과제번호: PJ01170701)의 연구비지원에 의해 수행 되었다.

\section{References}

1. Miller CD, Denning H, Bauer A (1952) Retention of nutrients in commercially prepared soybean curd. J Food Res, 17, 261-266

2. Park KN, Park LY, Kim DG, Park GS, Lee SH (2007) Effect of turmeric (Curcuma aromatica Salab.) on shelf life of tofu. Korean J Food Preserv, 14, 136-141

3. Kim JH, Woo EY, Kim KS, Kim MH (2006) A study on the soybean curd (tofu) made from defatted soybean flour. Kor J Food Nutr, 19, 22-27

4. Kweon MN, Ryu HS, Moon JH (1993) Nutritional evaluation of tofu containing dried soymilk residue (DSR)-1. Evaluation of protein quality. J Korean Soc Food Sci Nutr, 22, 255-261

5. Kang SH, Lee YW, Oh WT (1998) A study on characteristics of spoilage bacteria isolated from packed tofu. J Food Hyg Safety, 13, 383-387

6. Wu MT, Salunkhe DK (1977) Extending shelf-life of fresh soybean curds by in-package microwave treatments. J Food Sci, 42, 1448-1450

7. Oh SW, Lee YC, Hong HD (2002) Effects on the shelf-life of tofu with ethanol extracts of Rubus coreanus miquel, Therminalia chebula Retz and Rhus javanica. Korean J Food Sci Technol, 34, 746-749

8. Pontecorvo AJ, Bourne MC (1978) Simple methods for extending the shelf life of soy curd (tofu) in tropical areas. J Food Sci, 43, 969-972

9. Lee KS, Kim DH, Baek SH, Choun SH (1990) Effects of coagulants and soaking solutions of tofu (soybean curd) on extending its shelf life. Korean J Food Sci Technol, 22, $116-122$

10. Chun KH, Kim BY, Son TI, Hahm YT (1997) The extension of tofu shelf-life with water-soluble degraded chitosan as immersion solution. Korean J Food Sci Technol, 29, 476-481

11. Astushi M (1999) What is Chlorella. Food Ind, 9, 122-138

12. Lee YG, Lee HK (2002) Industrial using Algae. Microbial Biotechnol Lett, 15, 19-24

13. Bajguz A (2000) Effect of brassinosteroids on nucleic acids and protein content in cultural cells of Chlorella vulgaris. Plant Physiol Biochem, 38, 209-215

14. Kim DC, Won SI, In MJ (2014) Preparation and quality characteristics of Mul-kimchi added with Chlorella. J Appl Biol Chem, 57, 23-28

15. Park SI, Cho EJ (2004) Quality characteristics of noodle added with chlorella extract. Korean J Food \& Nutr, 17, 120-127

16. Park MK, Lee JM, Park CH, In MJ (2002) Quality characteristics of Sulgidduk containing chlorella powder. J Korean Soc Food Sci Nutr, 31, 225-229

17. Kim MJ, Shim CK, Kim YK, Hong SJ, Park JH, Han EJ, Jee HJ, Lee SB, Kim SC (2015) Effect of Chlorella sp. on improving antioxidant activities and growth promotion in organic soybean sprout cultivation. Korean J Org Agric, 23, 939-950

18. Kim MJ, Shim CK, Kim YK, Park JH, Hong SJ, Han EJ, Yoon JC (2014) Effect of Chlorella vulgaris CHK0008 fertilization on enhancement of storage and freshness in organic strawberry and leaf vegetables. Kor J Hort Sci Technol, 32, 872-878

19. AOAC (1995) Official Method of Analysis of AOAC Intl. 16th ed Method 991.43. Association of Official Analytical Communities, Arlington, VA, USA, pp. 95-100

20. Kim SS, Park MK, Oh NS, Kim DC, Han MS, In MJ (2003) Studies on quality characteristics and shelf-life of chlorella soybean curd (tofu). J Korean Soc Agric Chem Biotechnol, 46, 12-15

21. Jung GT, Ju IO, Choi JS, Hong JS (2000) Preparation and shelf-life of soybean curd coagulated by fruit juice of Schizandra chinensis RUPRECHT (Omija) and Prunus mume (Maesil). Korean J Food Sci Technol, 32, 1087-1092

22. Chang CI, Lee JK, Ku KH, Kim WJ (1990) Comparison of soybean varieties for yield, chemical and sensory properties of soybean curds. Korean J of Food Sci Technol, 22, 439-444

23. Lee BY, Kim DM, Kim KH (1990) Studies on the processing aptitude of the Korean soybean cultivars for 
soybean curd. Korean J Food Sci Technol, 22, 363-368

24. Smith AK, Watanabe T, Nash AM (1960) Tofu from Japanese and United States soybean. Food Technol, 14, 332-336

25. Wang HL, Swain EW, Kwolek WF (1983) Effect of soybean varieties on yield and quality of tofu. Cereal Chem, 60, 245-248

26. Beak SH, Kang KH, Choe SN (1996) Effect of seaweeds added in preparation of tofu (soybean curd). Korean J
Food \& Nutr, 9, 529-535

27. Kim KT, Im JS, Kim SS (1996) A study of the physical and sensory characteristics of ginseng soybean curd prepared with various coagulants. Korean J Food Sci Technol, 28, 965-969

28. Jeon MK, Kim MR (2006) Studies on storage characteristics of tofu with herb. Korean J Food Cookery Sci, 22, 307-313 